\title{
Fiscal policy under economic transformation
}

\author{
Zhanna Harbar \\ Department of Agrarian Management, \\ Vinnytsia National Agrarian University \\ Vinnytsia, Ukraine \\ garbar_janna@ukr.net \\ rtment of Economics and \\ International Relations, \\ Vinnytsia Institute of Trade and \\ Economics of Kyiv National University \\ of Trade and Economics Vinnytsia, \\ Ukraine \\ derkacholena@ukr.net
}

\author{
Victor Harbar \\ Department of Economics and \\ International Relations, \\ Vinnytsia Institute of Trade and \\ Economics of Kyiv National University \\ of Trade and Economics \\ Vinnytsia, Ukraine \\ garbarvictor@ukr.net
}

\author{
Serhii Sobchuk \\ Department Budget system, \\ Research Financial Institute of Kyiv \\ National University of Trade and \\ Economics \\ Kyiv, Ukraine \\ sisobchuk@gmail.com
}

\begin{abstract}
Approaches to functioning of fiscal policies in countries with developed and transformational economics are generalised and systematised with the view to enhance the efficiency of structural reforms of the financial system and to reduce the impact of fiscal imbalances on economic processes. Proved is the significance of more intensive fiscal decentralisation and implementation of earlier adopted programmes of the financial sector reform as well as the improvement of the coordination between monetary and fiscal policies. The authors substantiated the expediency of the financial system transformation by increasing fiscal transparency, decreasing tax burden on utilising labour resources, and improving mechanisms of control of complying with fiscal restrictions. It was established that the fiscal policy adaptation to current economic trends involves the formation of modern financial institutions, balancing the fiscal burden, and keeping to indicative values of the budget deficit and public debt, while contributing to the innovative transformation of the economy. Substantiated is the need to carry out weighed fiscal policies in the system of budgetary expenditures, including the readjustment of a debt policy with regard to the state budget balancing, working out a mediumterm debt strategy with account for endogenous and exogenous financial and economic factors. The importance of using the mechanism of managing a budgetary deficit through encouraging domestic loans is grounded. It has been established that measures of budgetary control aimed at macroeconomic stabilisation and securing sustained stability of the financial system of a country are assuming significance.
\end{abstract}

Keywords - fiscal policy, budgetary deficit, government debt, economic transformation.

\section{INTRODUCTION}

The processes of financial globalization increase the relevance of studying and analyzing the experience of fiscal policy formation in developed and transformational economies. The world practice and theoretical studies indicate the effectiveness of using modern management techniques to ensure sustainable economic development. The functioning of public finances is designed for the mid-term and is realized through the development and adoption of medium- and long-term financial strategies of the state and fiscal consolidation plans.
The role and significance of fiscal policy in the context of the transformation of the economy is confirmed in numerous scientific works. An important contribution to the study of fiscal impact on a country's economy was made in the work of Afonso, A., Jalles, J.T. "Fiscal composition and long-term growth" [1]. An analysis of the practice of the formation and use of financial resources of a country has shown that incomes do not have a significant effect on growth, while expenditures have a negative bearing. It has been proved that taxes on income are less significant for growth enhancing, as well as public wages, interest payments, subsidies and government consumption, while expenditure on education and health will boost growth.

While analyzing the correlation between the growth of real GDP and 10 different categories of public expenditure according to their functional classification, for 10 selected Central and Eastern European countries that joined the European Union the researchers Dan Lupu, Mihai Bogdan Petrisor, Ana Bercu and Mihaela Tofan [2] established that education and health spending has a positive impact on the economy, while expenditures on defense, economic affairs, general government services and social security have a negative bearing.

This indicates a significant role of the structure of expenditures on a country's economic system, while the level and characteristics of their distribution depend on a significant number of endogenous and exogenous factors of influence. However, general trends persist even in countries with different systems of distribution of financial resources.

António Afonso and Ricardo M. Sousa in the paper "The macroeconomic effects of fiscal policy" [3] confirm with Bayesian Structural Vector Auto regression (B-SVAR) that government spending shocks, in general, have a small effect on Gross Domestic Product (GDP) and lead to important 'crowding-out' effects. They also have a varied impact on housing prices and generate a quick fall in stock prices. Government revenue shocks generate a mixed effect on housing prices and a small and positive effect on stock prices. It is also important to confirm the need to take into account the size and structure of public debt in the process of characterizing the impact of the expenditure part of the 
budgets on the processes of economic development in a country.

\section{LITERATURE REVIEW}

Significant contribution to the development of fiscal instruments to overcome financial crises has been made by Besnik Fetai [4] in the article "The Effects of fiscal policy in the financial crisis in transition and emerging economies: does fiscal policy matter?" The author proved that anticyclical measures of fiscal policy have a positive effect on the reduction of the duration of a financial crisis. The results show that fiscal expansion may reduce the duration of a financial crisis in these countries by nine months. Anticyclical fiscal revenue reduction measures proved to be more effective than government consumption for reducing the duration of a crisis.

The authors of the monograph "Budgetary policy for social development" [5] highlighted the main methodological and institutional principles of fiscal policy formation for ensuring the social development. They systematized the experience of introducing fiscal policy in both developed and transformational economies. The proposed directions for increasing the efficiency and strengthening of the regulatory potential of the state tax policy are well-grounded in the above work.

In today's environment, processes that are associated with the expansion of the use of state-of-the-art technologies both in the business environment and in the public administration system become relevant. It is, therefore, expedient to expand approaches to the use of fiscal instruments in order to attract additional funds to the state budget. Thus, in the paper "Tax Control of Cryptocurrency Transactions in Ukraine" [5], the expediency of establishing a tax system for crypt-exchange transactions and tax control is justified. It is stated that the above measures will make it possible to receive additional revenues to the budgets, reduce the level of shadow economy, and counteract cyber-crime and terrorist financing.

Philip Arestis and Malcolm Sawyer in the study "The return of fiscal policy" [7] substantiate the need for fiscal policy to help create conditions for a high level of employment. Attention is also drawn to the highlighted approaches to the peculiarities of the balance of payments management by means of fiscal adjustment.

The Ukrainian scientists I. Chugunov and M. Pasichnyi (2018) in the research "Fiscal stimuli and consolidation in emerging market economies" [8] have proved that the level of institutional structure of their financial system is important in the process of implementation of effective fiscal policy. It has also been confirmed that episodes of expansionary fiscal adjustments based on government revenues and cost increases were more effective than those that were fully based on cost increases. This indicates the special importance of the fiscal mechanism in the process of regulating the socio-economic development of a country.

The team of authors of the "Dynamic Analysis of Endogenous Growth Models with Fiscal Decentralization and Local Government Debt" [9] argue that the government debt issues have received extensive attention around the world. The endogenous growth theory and the Hamilton function method proved to be instrumental for obtaining the explicit solution of fiscal revenue decentralization, fiscal spending decentralization, and local government debt.

In today's context, the issue of increasing fiscal transparency is gaining momentum, as evidenced by Yaqin Yang in the work "Improving Fiscal Transparency in Government Comprehensive Financial Report Reform: How Fiscal Transparency should be in China" [10], where a clear distinction is made between fiscal transparency and budget transparency. It has been determined that fiscal transparency does not only suggest open budget information, but also fiscal policy adoption, fiscal policy efficiency, among others.

Thus, analyzing the approaches of foreign and domestic scientists to the peculiarities of implementing effective fiscal regulation aimed at restoring the ascending dynamics of the economic development, it is expedient to characterize its introduction under conditions of economic transformation.

\section{PROBLEM ISSUE}

Fiscal policy as one of the most important instruments for coordinating economic activity of a state creates conditions for redistribution of financial resources in the national economy on the principles of rationality and efficiency as well as compliance with the economic policy implemented in the country. In order to stimulate the development of productive forces and promote scientific and technological progress in the context of the transformation of the economy, it is worthwhile to use fiscal regulation aimed at providing structural and innovation restructuring of the economic system. Thus, the fiscal mechanism for implementing a state policy to stimulate a stable growth, even in the most liberal models of national economies, such as the US and the European Union, plays a leading role in the state regulation of the economy. State expenditures in this case play a significant role in the structure of investment in fixed assets and have a side effect on the real sector of the economy.

In order to systematize approaches to the functioning of fiscal policy in countries with developed and transformational economies, comparative, statistical and factor methods are used. By means of employing methods of scientific abstraction and synthesis, the priority directions of the budget policy as a tool of state financial regulation are determined. The set of methods and approaches applied in the work allowed to realize the conceptual unity of the research.

\section{FUNDAMENTALS OF THE IMPLEMENTATION OF FISCAL REGULATION OF ECONOMIC DEVELOPMENT}

The budget policy of the European Union is implemented on the basis of generally accepted principles of effective state financial regulation: the principle of unity and budget accuracy requires the inclusion and coverage of all EU incomes and expenditures in a single legal document; the principle of timeliness or periodicity implies the adoption of a budget for one budget year and the use of planned financial resources for the current financial period during it; the principle of equilibrium is characterized by the equality of income and expenditure part of the budget; the principle of the unit of account involves the use of a single currency in the planning and execution of the budget; the principle of universality determines the use of the general income for the implementation of general budget expenditures, with the exception of a limited number of revenues allocated for 
specific purposes; the specification principle characterizes the allocation of financial resources for a specific purpose solely; the principle of sound financial management is based on the principles of economic feasibility, efficiency and effectiveness; the principle of transparency (openness) involves ensuring free access and reliability of information on budget accounts and the stages of implementation of budgetary regulation. The formation of the revenue part of the EU budget is based on contractual constraints on the absence of a deficit, i.e. the covering of all expenditures on income received, and the establishment and agreement of the maximum cost of the European Union.

The peculiarities of the EU finances lie in the fact that they are formed entirely at the expense of their own financial resources, without limiting other types of sources, and their direct collection and transfer to the EU budget is directly committed by the participating countries. In order to maintain budgetary discipline, the European Union does not make any decisions that may have significant budgetary implications without providing guarantees regarding the possibility of financing within the Union's own funds. That is why the principle of balance of revenues and allocations for a budget year is very important. Borrowing to cover any budget deficit that may arise is incompatible with the EU's own resource system.

TABLE I. SPECIFIC WEIGHT OF THE MAIN BUDGET INDICATORS OF THE EUROPEAN UNION IN GROSS DOMESTIC PRODUCT, \%

\begin{tabular}{|c|c|c|c|c|c|}
\hline & & $\begin{array}{l}2004- \\
2008\end{array}$ & $\begin{array}{l}2009- \\
2013\end{array}$ & $\begin{array}{l}2014- \\
2018\end{array}$ & $\begin{array}{l}2004- \\
2018\end{array}$ \\
\hline \multirow{4}{*}{$\begin{array}{l}\stackrel{0}{\Xi} \\
\stackrel{0}{0} \\
\stackrel{0}{0}\end{array}$} & $\begin{array}{l}\text { General } \\
\text { government }\end{array}$ & 43.4 & 44.2 & 44.8 & 44.1 \\
\hline & Central government & 23.6 & 23.4 & 23.8 & 23.6 \\
\hline & State government & 4.1 & 4.4 & 4.6 & 4.4 \\
\hline & Local government & 10.9 & 11.4 & 10.9 & 11.1 \\
\hline \multirow{4}{*}{ 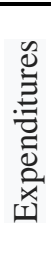 } & $\begin{array}{l}\text { General } \\
\text { government }\end{array}$ & 45.5 & 49.2 & 46.5 & 47.1 \\
\hline & Central government & 25.6 & 27.7 & 25.6 & 26.3 \\
\hline & State government & 4.3 & 4.8 & 4.7 & 4.6 \\
\hline & $\begin{array}{l}\text { General } \\
\text { government }\end{array}$ & 11.0 & 11.7 & 10.8 & 11.2 \\
\hline \multirow{4}{*}{ 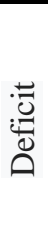 } & $\begin{array}{l}\text { General } \\
\text { government }\end{array}$ & 2.9 & 5.0 & 1.7 & 2.9 \\
\hline & Central government & 2.0 & 4.3 & 1.8 & 2.7 \\
\hline & State government & 0.1 & 0.4 & 0.1 & 0.2 \\
\hline & $\begin{array}{l}\text { General } \\
\text { government }\end{array}$ & 43.4 & 44.2 & 44.8 & 44.1 \\
\hline
\end{tabular}

Source: compiled by the author based on Eurostat Data Access Mode: http://ec.europa.eu/eurostat/data/database

The dynamics of the general budget revenues of the European Union is characterized by an increase from 43.4 per cent for the period of 2004-2008 to 44.2 per cent in the years 2009-2013 and to 44.8 per cent in the years 2014-2018. For the period of 2004-2018, the average value of this indicator was 44.1 per cent, which is a very significant value and the one that corresponds to the general trends of development of the EU member-states. According to the indicators of the redistribution of the gross domestic product through the state budget revenues, three models of budget relations can be distinguished: the first model - the share of budget revenues in a country's GDP is 30-40 per cent, which is typical of countries with transformation economies such as Latvia - 37.2 per cent, Lithuania - 36.7 per cent, Estonia 37.9 per cent, and Romania - 36.3 per cent. The second model suggests that the share of income of developed economies reaches $40-50$ per cent: Germany -45.3 per cent, Italy -48.9 per cent, Great Britain -43.2 per cent, Norway 44.8 - per cent, and Poland - 43.7 per cent. The third model refers to socially oriented countries with a centralized share of GDP of 50 per cent and more: Denmark - 53.9 per cent, France -54.7 per cent, Finland - 52.6 per cent, and Sweden - 51.8 per cent. In Ukraine, the share of consolidated budget revenues in gross domestic product is currently 30.2 per cent, which is lower than the average in the countries of the European Union.

For so-called "transitive" countries that face significant budgetary constraints, such a tool is extremely important and allows territorial systems to use additional resources to cofinance development projects while retaining opportunities to cover current costs through their own resources. At the same time, the main objects of the regional policy of the EU are their own regions, not municipalities or communes. Therefore, decentralized models of EU member- states often establish more regional development-related responsibilities, while current economic and social issues are addressed locally [11].

The characteristic of the share of government revenues in the gross domestic product of the countries of the European Union makes it possible to distinguish between three groups of countries in terms of the centralization of financial resources in their budget (Fig. 1).

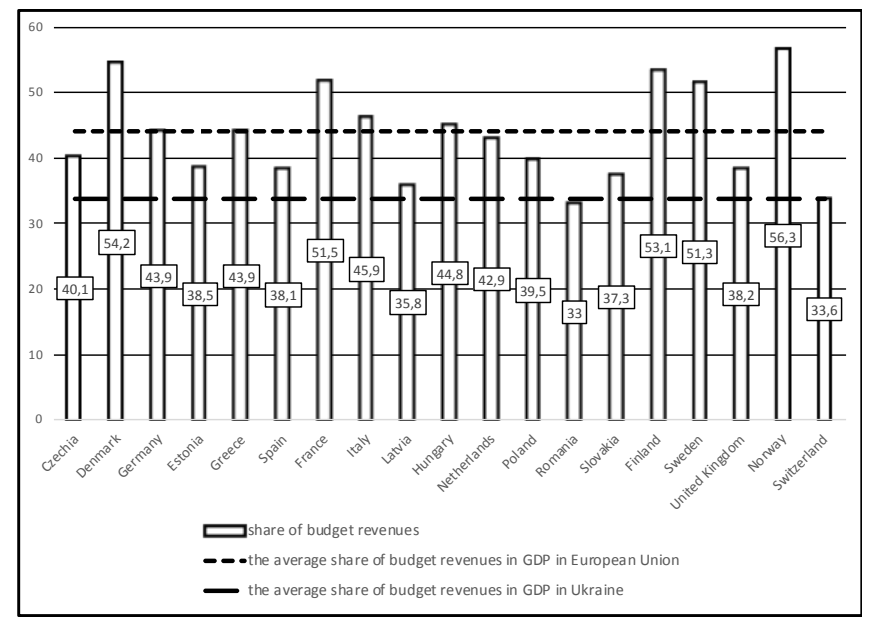

Fig. 1. The average share of budget revenues in GDP in the countries of the European Union in 2004-2018, \%

As shown in Fig. 1., countries with a socially oriented economies have a centralised GDP of 50 per cent or more (Denmark - 54.2 per cent, France - 51.5 per cent, Finland 53.1 per cent, Sweden -51.3 per cent, and Norway - 56.3 per cent). In countries with a transformational economy, this indicator varies between 30-40 per cent: Estonia - 38.5 per cent, Latvia - 35.8 per cent, Romania - 33.0 per cent, Slovakia -37.3 per cent. In highly- developed countries, the centralised gross domestic product is in the range of 40-50 per cent: Germany 43.9 per cent, Italy -45.9 per cent, the Netherlands - 42.9 per cent, and the United Kingdom - 38.2 per cent. This indicates the importance of not only the 
mechanism of using the revenue part of the budget, but also the methods of its accumulation. Due to the increase of resources concentrated in the state budget, the state can directly influence the indicators of aggregate demand and supply as well as regulate the consumer price index and the level of employment of the population.

It is expedient to describe the existing sources of the general budget revenues of the European Union. Thus, own sources take into account the customs duties charged according to the Common Customs Tariff. It is worth noting that revenues from customs duties can be recognised as revenues of the entire EU, rather than individual countries, as they cope with all economic actors operating outside its borders. The next source of the revenue part of the EU budget is the contributions of individual countries, calculated on the basis of their gross national income. A significant proportion of these contributions serve to cover the difference between planned expenditures and revenue from the general budget from these sources. This difference, calculated for the whole organisation, should be covered by EU members in proportion to the national share of each country in the aggregate national income of the European Union. This concept of generic budgeting means that the larger its expenditure part is not covered by revenue from customs duties and VAT, the larger are direct withdrawals from the budgets of the participating countries.

An important place in implementing the fiscal policy of a country is its tax system. The size and characteristics of tax payments paid by individuals and legal entities determine the ability of a country to exercise its functions and provide them with adequate financial resources. It is the size of the general tax rate and the share of taxes in the gross domestic product that may reflect the chosen direction of development of economic relations in a country and the method of their state regulation.

The share of taxes on production and imports in the gross domestic product of the European Union countries for the years 2007-2016 is 13.06 per cent. Yet there is a tendency towards the increase of this indicator. Thus, over the fiveyear period, in 2007-2011 it was 12.76 per cent, in 2012$2016-13.36$ per cent. This indicates an increase in the role of taxes in the formation of the Union budget and the use of this method of accumulation of financial resources after the withdrawal of financial-recessionary countries. That is, it can be noted that during the fall of the indicators of economic development in 2008-2009, a decision was made to stimulate economic development and the internal aggregate demand by increasing the share of state revenues by increasing the tax burden on the economic system.

Sweden has a significant share of tax revenues for production and imports in GDP - 22.14 per cent in 20072016, Denmark - 16.45 per cent, and France - 15.26 per cent. In the first two countries, due to a well-balanced fiscal policy during the recession, there was even a drop in tax revenues from 16.56 per cent in the years 2007-2011 to 16.34 per cent in the years 2012-2016 in Denmark and 22.2 per cent in the years 2007-2011 to 22.08 per cent in the years 2012-2016 in Sweden. Switzerland has the lowest incomes of taxes on production and imports -6.16 per cent in the years 2007-2016, Germany 10.8 - per cent, Spain -10.64 per cent, and Slovakia - 10.43 per cent.
In the context of overcoming the effects of the financial crisis in the countries across the world and Ukraine, in particular, the role of fiscal policy in the field of public expenditures as an integrated system of measures and actions of the authorities in managing budget funds is growing on the basis of the concept of development of budgetary relations. The budget policy of Ukraine and the EU countries should promote state support for the growth of the national economy, ensuring financial and social stability, meeting the needs and solving the various problems of society on the basis of sustainable development. State expenditures are a resource base of state authorities and management in conducting budget policy and implementing social and economic reforms aimed at ensuring economic growth. Therefore, the formation of the optimal composition and structure of public expenditures in the system of fiscal policies of the EU and Ukraine is one of the priority tasks at the present stage of socio-economic development [12].

The principles of organisation and implementation of expenditure powers of the European Union countries regarding the selection of optimal directions of use of available financial resources are of great importance (Figure 2).

The overwhelming majority of the European Union countries show a share of spending on public sector business financing in the range close to the EU average. Expenditures on social security play a significant role in the budget policy of the countries with a transformational economy, which in turn determines their development vectors.

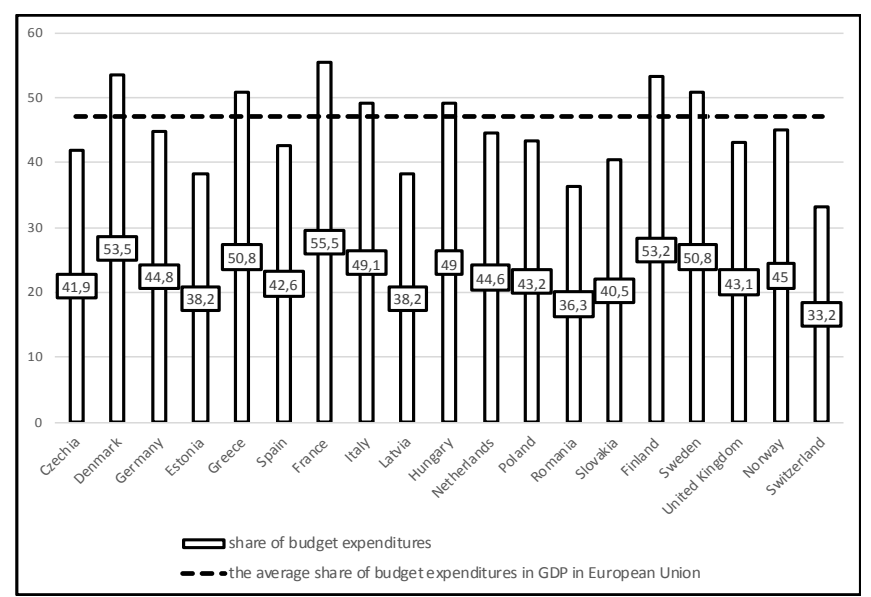

Fig. 2. The average share of budgetary expenditures in GDP in the countries of the European Union in the years 2007-2016, \%

The budget policy of the European Union regarding the regulation of the expenditure part of the budget is based on the structuring of expenditures for the priority goals of the socio-economic development and the achievement of maximum effect with the use of the minimum amount of resources. The average share of budget expenditures in GDP in the countries of the European Union in the years 20042018 is 47.1 per cent and exceeds the revenue side by 3.0 per cent. However, the dynamics of the key indicators is similar and fully corresponds to the measures of financial and budgetary regulation, which are carried out within the limits of the Union.

An important task of financial and budgetary regulation in countries with a developed and transformational economy 
is the management of indicators of inflation and measures for its targeting. It is established that there is a correlation between the indicators of the share of budget expenditures in GDP and the consumer price index, indicating the possibility of adjusting these indicators with the help of budgetary control instruments. In the countries of the European Union there is a well-balanced anti-inflationary policy, which depends not only on the inflation rate, but also on the priorities of fiscal policy and sustainable economic development. The main anti-inflationary instruments in this case are measures based on monetary-indexing of incomes, application of the mechanism of adjustment of interest rates in accordance with inflation rates, and fiscal policy changes in the taxation system, the introduction of rigorous state control over prices and wages [13].

It is also necessary to adapt all economic institutions to functioning under conditions of inflation. An important component of the anti-inflationary strategy is the readjustment of public finances, primarily the reduction of budget deficits and public debt. In most developed countries of the world there is a tendency to exceed the volume of public debt index of international currency reserves. This indicates a change in the international financial markets, the availability of financial resources, especially for advanced economies, and the possibility of using debt instruments to finance public expenditures. Of the countries represented, only in China reserves are dominated by liabilities ( 5.99 per cent); in all other countries there is a significant excess of debt instruments over foreign exchange reserves: in Japan 200 per cent, in France - 91.31 per cent, in the UK - 84.08 per cent, in Germany - 67.06 per cent, in the United States 70.99 per cent, and in Ukraine - 92.77 per cent.

Budget policy in the field of public debt management has been the most important tool for reducing negative crises developments by attracting additional financial resources from both internal and external sources. The problems that arise in the post-crisis period in this area are related to the high degree of credit dependence of developed economies. Thus, the budget policy of foreign countries can identify the following trends or models of management of the budget sphere. The first model is characteristic of developed countries that are striving to reduce their budget deficits, mainly due to cost reductions and direct savings in financial resources, and in some acute crisis cases (e.g. Greece, Portugal, and Spain) - due to the gradual increase in tax burden [14].

Nowadays, the possible aggravation of problems in the debt market of a country is caused by the presence of a deficit of the state budget, the need for implementation of budget savings measures, and the growth of deficits of local budgets. The need for stabilisation of the economy, the need for financial consolidation of the member-countries of the Euro-zone may slow down the economic development process, reduce tax revenues to the state budget and inflow for infrastructure development from the European Union.

In today's conditions, when the problems of control over the state budget deficit, the choice of sound fiscal policy and the reduction of the public sector's share in the economy are becoming more and more acute, governments in many developed countries, as well as regions and large cities, have substantially reformed the budget process. One of such reforms in many countries was the transition to a multi-year financial plan.

The European Union's financial stabilisation plan for the years 2015-2017 suggests spending savings of 50 billion euros by 2017 in order to bring the budget deficit in line with European standards of 3 per cent of GDP. Savings are expected to be spent at the expense of a reduction of the state's central administration - 18 billion euros, a system of social protection and public support -11 billion euros, a health insurance system - 10 billion euros, local budgets (municipalities, departments, regions) - 11 billion euros. With the introduction of additional taxes for households and enterprises, it is planned to receive 3 billion euros.

The abolition of tax preferences for wealthy corporations and corporations will allow the United States to attract about $\$ 60$ billion in the United States. Among other things, hedge funds and private equity funds will attribute their interest on profits not to capital gains, but to the tax on ordinary profits of the company. In the medium term, achieving a reduction in the federal budget deficit will be achieved by reducing federal spending, and the rest - due to the reform of taxation and savings in servicing public debt. Thus, from the implementation of the health care reform, additional revenues to the federal budget by 2019 should be 409.2 billion dollars. The United States, in particular, cancelled the health insurance premium of $\$ 210.2$ billion, $\$ 32.0$ billion in excise taxes on health insurance, and $\$ 20$ billion in the excise tax on manufacturers and importers of medical equipment.

In the UK, the government seeks to balance the budget in the years 2018-2019 by setting the expected budget deficit. In order to achieve this in the medium term, it is necessary to gradually reduce public expenditures and loans in order to ensure economic stability. Among other things, it is planned: to provide an annual budget savings of 1 billion pounds by reducing funding for public institutions; to reform the country's retirement policy through the introduction of a new formula, tied to the average life expectancy in the UK (thus, the retirement age will be gradually increased to 69 years old, which will reduce public spending by 400 billion pounds sterling); to reduce the budget deficit by ensuring a balanced tax policy. To achieve this goal, it is planned to increase control over tax evasion cases as well as to provide control over financial discipline by increasing the fight against fraud and errors in social payments systems. The implementation of these measures is expected to generate additional 9 billion pounds sterling in the next five years.

Of considerable importance is the development of forecasts for socio-economic development of a country. The experience of the US indicates the expediency of using consensus forecasts. Thus, the estimation of promising incomes of the USA is carried out in one of four ways: forecasting of budget revenues is carried out jointly by executive and legislative bodies, forecasts of legislative authorities are usually carried out by research agencies or separate specialised divisions which are part of the legislative committee. In turn, forecasts of the executive branch of government are prepared by the state budget bodies or state revenue institutions; preparing a forecast of budget revenues by executive authorities is the estimation of perspective incomes prepared by the department of financial management. Projections of income by legislative bodies of 
state power is the preparation of income forecasts for the next year, which is carried out by the Joint Legislative Committee of the budget with participation of the external financial advisory committee, state university and other independent experts. In turn, the Treasury uses the information received to determine the amount of revenue that the state will receive over the next two years. In general terms this approach is quite rarely applied in the course of forecasting tax revenues. The consensus-forecast with the participation of independent experts consists in creating a unified forecast, combining the efforts of the legislative and executive authorities and adhering to the budget constraint [15].

Thus, fiscal consolidation in developed and transformational economies is carried out with the aim of increasing the sustainability of public finances and is a set of measures aimed at increasing budget revenues and optimising budget expenditures by implementing a structural adjustment of the budget and tax system.

It is important to improve the cyclically-adjusted budget balance, which, in the medium-term perspective, will allow for stable economic growth, and increase the employment rate of the population. Measures on financial regulation of the budget system are aimed at balancing the volume of revenues and expenditures of the general government sector, incomes entering the budget system and state trust funds, optimising volumes and improving the structure of budget expenditures, increasing the efficiency of the use of financial resources, reducing the direct and guaranteed burden of the state debt to the budget system of a country. Most countries of the world in recent years have adhered to the policy of hard budget savings, budget discipline, transparency of the budget, which contributes to reducing debt obligations, budget deficit.

\section{CONCLUSIONS}

Fiscal policy is an effective instrument for ensuring macroeconomic stabilization and further enhancing economic development processes. The task of fiscal regulation regarding the formation of an efficient allocation of financial resources should be coordinated with the strategic goals of sustainable economic growth and increase of living standards of the population. It is important to ensure macroeconomic stability, to establish optimal structural proportions in the economy, to improve social policy, and to form modern financial institutions. Under conditions of transformation and slowdown of the growth of the world economy, measures of fiscal policy, which are implemented in countries with developed and transformational economies, are aimed at stimulating domestic demand. The priority measures of fiscal policy are reducing structural budget deficit and public debt, optimizing budget expenditures, improving fiscal efficiency of the tax system, and increasing the effectiveness of the budget planning and forecasting mechanism. Important is the implementation of systemic measures to raise the level of current liquidity of the financial system; redemption of financial assets of troubled assets in order to improve their balance sheets and expand the possibilities of lending to the economy; the implementation of state investments in the capital of financial institutions. Possibilities of stimulating the economy due to fiscal policy are limited. Therefore, it is expedient to simultaneously carry out structural changes of the system of public finances and to increase the influence of divergent factors on economic processes.

\section{REFERENCES}

[1] A. Afonso, and J. Jalles, "Fiscal composition and long-term growth", Applied Economics, vol. 46, no. 3, pp. 349-358, 2014. [Online]. Available: https://doi.org/10.1080/0 0036846.2013.848030. Accessed on: May 29, 2019.

[2] D. Lupu, M. B. Petrisor, A. Bercu and M. Tofan, "The Impact of Public Expenditures on Economic Growth", A Case Study of Central and Eastern European Countries, Emerging Markets Finance and Trade, vol. 54, no. (3), pp. 552-570, 2018. [Online]. Available : https://doi.org/10.1080/1540496X.2017.1419127. Accessed on: June 5, 2019.

[3] A. Afonso and R. M. Sousa "The macroeconomic effects of fiscal policy", Applied Economics, vol. 44, no. 34, pp. 4439-4454, 2012. [Online]. Available : https://doi.org/10.1080/00036846.2011.591732. Accessed on: June 5, 2019.

[4] B. Fetai "The effects of fiscal policy during the financial crises in transition and emerging countries: does fiscal policy matter?" Economic Research, vol. 30, no. 1, pp. 1522-1535, 2017. [Online]. Available: $\quad$ https://doi.org/10.1080/1331677X.2017.1340181. Accessed on: June 5, 2019.

[5] I. Chugunov, V. Makohon, and M. Pasichnyi, Budget policy of social development. Tallinn: Scientific Route, 2018

[6] S. Volosovych, and Y. Baraniuk, "Tax control of cryptocurrency transactions in Ukraine”, Banks and Bank Systems, no.13 (2), pp. 89106, 2018. Doi:10.21511/bbs.13(2).2018.08

[7] P. Arestis, and M. Sawyer, "The return of fiscal policy", Journal of Post Keynesian Economics, vol. 32, no. 3, pp. 327-346, 2010. [Online]. Available: doi:10.2753/PKE0160-3477320301. Accessed on: June 5, 2019.

[8] I.r Chugunov and M. Pasichnyi, "Fiscal stimuli and consolidation in emerging market economies", Investment Management and Financial Innovations, no. 15(4), pp. 113-122, 2018. Doi:10.21511/imfi.15(4).2018.09

[9] J. He, L.-L. Liu, S. Cao, Y.-J. Zhang, and S.-Y. Tang, "Dynamic Analysis of Endogenous Growth Models with Fiscal Decentralization and Local Government", Debt. International Conference on Social Science, Humanities and Modern Education, 2016.

[10] Yaqin Yang, "Improving Fiscal Transparency in Government Comprehensive Financial Report Reform: How Fiscal Transparency should be in China", Proceedings of the 2016 International Conference on Public Management (ICPM 2016). Doi: 10.2991/icpm-16.2016.93

[11] B. M. Danylyshyn, and V. V. Pylypiv, "Decentralization in the EU countries: lessons for Ukraine" Regional Economy, no 1, pp. 5-11, 2016.

[12] I. Boyarko, N. Dehtyar, and O. Deyneka,"Analysis of fiscal policy of the EU and Ukraine in the sphere of formation and use of state expenditures", Bulletin of the National Bank, no 9, pp. 17-21, 2013.

[13] I. N. Udina, Financial Integration: The Experience of Emerging Market Countries. Kyiv: Institute for the Economy in Transition, 2015.

[14] O.D. Rozhko, "Practice of formation the own financial resources of the EU budget under condition of integration of the national system of state finance", Scientific journal of ChSIEM, vol. 4., pp. 172-178, 2013. [Online]. Available : http://nbuv.gov.ua/UJRN/NvChdieu _2013_4_26. Accessed on: June 5, 2019.

[15] M.B. Dedusheva, "Features of forecasting of local budgets in the United States of America" Socio-Economic Research Bulletin, vol. 2, pp. 51-60, 2015. [Online]. Available: http://nbuv.gov.ua/UJRN/Vsed_2015_2_8. Accessed on: June 5, 2019 